\title{
Rozległy ropień lewej przestrzeni zaotrzewnowej o niewyjaśnionej etiologii, przebijający się do jamy otrzewnej - opis przypadku
}

\section{Excessive left retroperitoneal abscess of an unknown aetiology perforating into the peritoneal cavity: a case report}

\author{
Andrzej Żyluk, Piotr Puchalski, Piotr Janowski \\ Klinika Chirurgii Ogólnej i Chirurgii Ręki Pomorskiego Uniwersytetu Medycznego w Szczecinie \\ ul. Unii Lubelskiej 1, 71-252 Szczecin \\ Kierownik: prof. dr hab. n. med. Andrzej Żyluk
}

\begin{abstract}
Retroperitoneal abscesses present a relatively uncommon complication of diseases of various abdominal organs, although most commonly they are related to acute appendicitis of retrocoecal location. The paper presents the case of a healthy patient in whom an excessive left retroperitoneal abscess developed, perforated into the peritoneal cavity, and almost perforated through the skin in XII ${ }^{\text {th }}$ intercostal space. The patient had no abdominal symptoms or signs, but complained from slight pain in the left
\end{abstract}

lumbar area. The diagnosis was established based on abdominal computed tomography scanning and an operative treatment by laparotomy. The evacuation and drainage of the abscess was effective and the patient recovered. Bacteriological examination of the pus from the abdominal cavity revealed single colonies of anaerobic Fusobacterium species. The cause of the occurrence of the abscess remained unknown.

Keywords: retroperitoneal abscess, unknown aetiology, Fusobacterium species.

\section{STRESZCZENIE}

Ropnie przestrzeni zaotrzewnowej to stosunkowo rzadko występujące powikłanie schorzeń różnych narządów jamy brzusznej, najczęściej ostrego zapalenia wyrostka robaczkowego, szczególnie położonego zakątniczo.

W pracy przedstawiono przypadek dotychczas zdrowego pacjenta, u którego rozległy ropień powstał w lewej przestrzeni zaotrzewnowej, przebił się do jamy otrzewnowej i prawie przebił się przez skórę w XII przestrzeni międzyżebrowej. Pacjent nie miał objawów brzusznych, tylko skarżył się na umiarkowany ból

w lewej okolicy lędźwiowej. Rozpoznanie ustalono na podstawie badania tomografii komputerowej jamy brzusznej, a leczenie operacyjne przez laparotomię, ewakuację i drenaż ropnia było skuteczne, gdyż pacjent wyzdrowiał. Badanie bakteriologiczne ropy z jamy brzusznej wykazało nieliczne kolonie bakterii beztlenowej Fusobacterium species. Przyczyna powstania ropnia pozostała nieustalona.

Słowa kluczowe: ropień zaotrzewnowy, nieznana etiologia, Fusobacterium species.

\section{WSTĘP}

Ropnie przestrzeni zaotrzewnowej stanowią stosunkowo rzadko występujące powikłanie schorzeń różnych narządów jamy brzusznej. W porównaniu do ropni wewnątrzotrzewnowych, których przyczyną są zwykle zapalenia narządów wewnątrzbrzusznych lub powikłania pooperacyjne (nieszczelność zespoleń jelitowych, zakażone krwiaki), powody ropni zaotrzewnowych są znacznie bardziej urozmaicone. Mogą być powikłaniami perforacji przewodu pokarmowego do przestrzeni zaotrzewnowej: owrzodzenia trawiennego lub uchyłka dwunastnicy, zapalnia zmienionego wyrostka robaczkowego lub uchyłka okrężnicy, raka okrężnicy, ale także jatrogennej perforacji dwunastnicy w czasie sfinkterotomii $[1,2,3,4]$. Inną przyczyną są zapalenia narządów położonych zaotrzewnowo - odmiedniczkowe zapalenie nerek i ostre zapalenie trzustki. Mogą być powikłaniem (zropieniem) pourazowych krwiaków zaotrzewnowych, często obserwowanych u pacjentów ze złamaniami kręgosłupa lędźwiowego i miednicy. Ropnie zaotrzewnowe mogą powstawać w przebiegu choroby Leśniowskiego-Crohna, ropnego zapalenia lub gruźlicy kręgosłupa lędźwiowego, albo jako przerzutowe drogą krwionośną, np. w przebiegu bakteryjnego zapalenia wsierdzia.

Objawy ropni przestrzeni zaotrzewnowej są różne, zwykle jednak dolegliwości odczuwane są w okolicy lędźwiowej, a znacznie rzadziej w jamie brzusznej. W zależności od przyczyny, ropień może znajdować się w górnej (pochodzenia trzustkowego i dwunastniczego) lub w dolnej (pochodzenia okrężniczego, wyrostkowego, urazowego) części tułowia. Ze względu na brak barier anatomicznych, cechą charakterystyczną tej patologii jest skłonność do szerzenia się w luźnej tkance łącznej, co sprzyja osiąganiu znacznych rozmiarów i nadaje im charakter ropowicy. Z tego też powodu szybko mogą powodować posocznice, szczególnie u osób w podeszłym wieku, chorych na cukrzycę i z osłabioną odpornością.

W pracy przedstawiono przypadek dotychczas zdrowego pacjenta, u którego rozległy ropień powstał w lewej przestrzeni 
zaotrzewnowej, przebił się do jamy otrzewnowej i prawie przebił się przez skórę w XII przestrzeni międzyżebrowej. Przyczyna powstania ropnia pozostała nieustalona.

\section{SPOSTRZEŻENIE WŁASNE}

Sześćdziesięcioletni, dotychczas zdrowy mężczyzna został skierowany na oddział chirurgiczny przez lekarza z poradni z powodu podejrzenia ropnia przestrzeni zaotrzewnowej po stronie lewej. Pacjent zgłosił się do lekarza z powodu trwającego ok. tygodnia bólu lewej okolicy lędźwiowej i stanów podgorączkowych. Po wizycie został skierowany na badanie USG brzucha z powodu podejrzenia odmiedniczkowego zapalenia lewej nerki, prawdopodobnie na tle kamiczym. Jednak badanie nie wykazało patologii lewej nerki, tylko obecność ropnia przestrzeni zaotrzewnowej po stronie lewej.

Przy przyjęciu mężczyzna był w stanie dobrym, skarżył się na umiarkowanie nasilony, stały ból lewej okolicy lędźwiowej. Dokładny wywiad potwierdził informacje od lekarza kierującego, że ból pojawił się tydzień wcześniej w lewym boku i lewej okolicy lędźwiowej i nie zmienił nasilenia ani lokalizacji do czasu zgłoszenia się do szpitala. Pacjent nie wymiotował, oddawał regularnie stolec, nie miał objawów ze strony układu moczowego. Badaniem przedmiotowym stwierdzono brzuch miękki, niebolesny przy badaniu, bez objawów otrzewnowych. Bolesność przy głębszym ucisku pojawiała się w lewym boku na wysokości XI i XII żebra. Objaw Goldflama był obustronnie ujemny. Ciepłota ciała wynosiła $37^{\circ} \mathrm{C}$. Badania biochemiczne wykazały znacznie podwyższone parametry stanu zapalnego: liczbę leukocy tów 20 G/L, stężenie CRP 340 mg/L. Badanie USG wykonane ambulatoryjnie wskazywało na przestrzeń płynową w lewej okolicy zaotrzewnowej. Wobec takiego obrazu klinicznego, wyników badań biochemicznych i USG zdecydowano o wykonaniu tomografii komputerowej jamy brzusznej z kontrastem, które ujawniło duży ropień okołośledzionowy będący w łączności z rozległym ropniem lewej przestrzeni zaotrzewnowej (ryc. 1-3). Treść ropna była obecna także w miednicy małej.

Pacjent został zakwalifikowany do laparotomii. Spodziewając się zakażenia florą z jelita grubego, przed operacją podano antybiotyki - ceftriakson z metronidazolem. Jamę brzuszną otwarto cięciem przyprostnym lewym. W jamie otrzewnowej stwierdzono umiarkowaną objętość mętnego płynu, a w zatoce Douglasa treść ropną. Jelito cienkie było miejscami posklejane włóknikiem. Po odsunięciu jelita cienkiego i zstępnicy stwierdzono wyciek dużej objętości ropy z okolicy lewego podżebrza. W tylnej ścianie jamy brzusznej, na wysokości XII żebra stwierdzono otwór, przez który wydobywała się ropa z przestrzeni zaotrzewnowej. Uruchomiono zgięcie śledzionowe okrężnicy i nacięto tylną ścianę jamy brzusznej wzdłuż zstępnicy, odsłaniając rozległą jamę ropnia wypełnioną masami martwiczymi, które ewakuowano. Łącznie z jamy otrzewnowej i z jamy ropnia odessano 1,5 L gęstej ropy. Zapach wydobywający się z ropnia nie był typowy dla zakażenie pałeczką okrężnicy (E. coli), a uczestnicy operacji określali go jako „chemiczny”. Pomimo anatomicznej bliskości lewej nerki i okrężnicy zstępującej nie

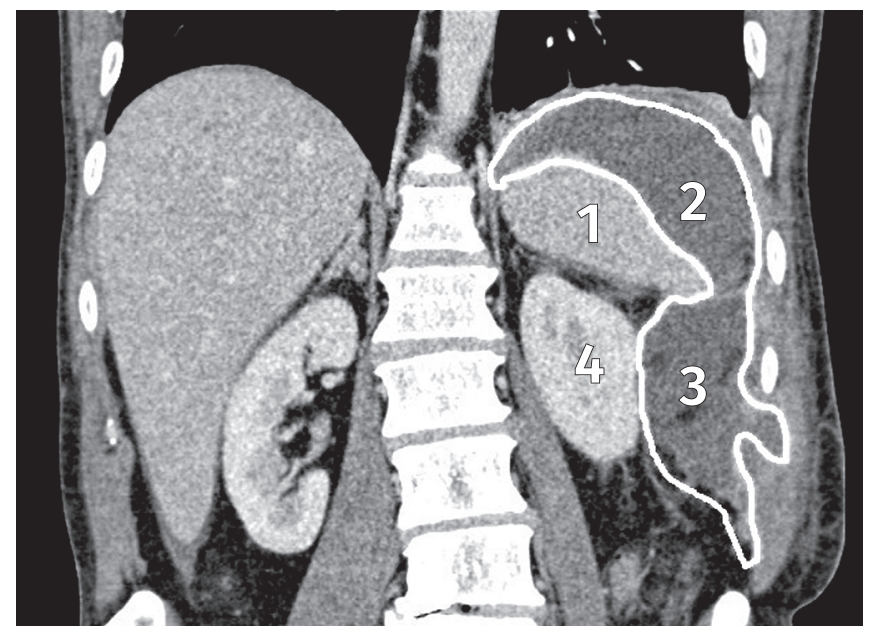

RYCINA 1. Tomografia komputerowa jamy brzusznej przed operacją w projekcji p-a, 1 - śledziona; 2 - ropień nadśledzionowy; 3 - ropień zaotrzewnowy; 4 - lewa nerka

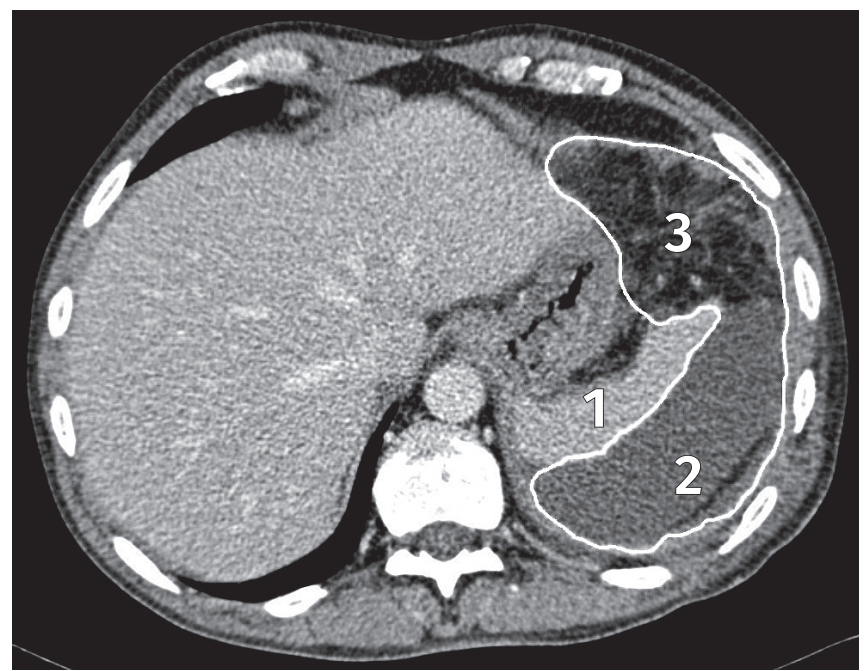

RYCINA 2. Tomografia komputerowa jamy brzusznej przed operacją w projekcji poziomej. 1 - śledziona; 2 - ropień nadśledzionowy; 3 - ropień zaotrzewnowy

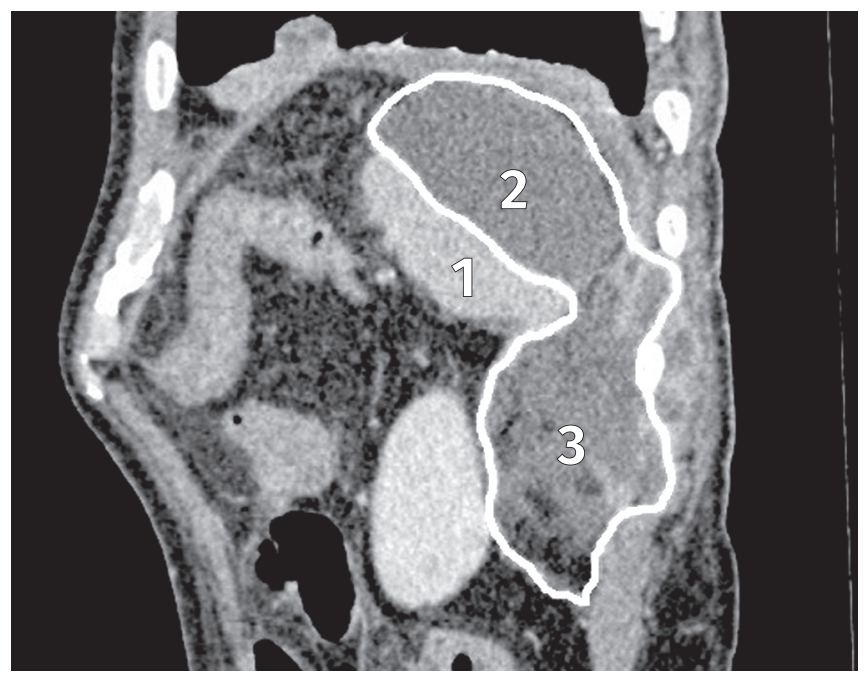

RYCINA 3. Tomografia komputerowa jamy brzusznej przed operacją w projekcji strzałkowej, 1 - śledziona; 2 - ropień nadśledzionowy; 3 - ropień zaotrzewnowy 
wykazano makroskopowo związku między ropniem a tymi narządami. Odkryto natomiast, że ropień przebijał się pod skórę w przestrzeni pod XII żebrem po stronie lewej. Wypłukano jamę otrzewnową, stwierdzając niewielkie ilości ropy w prawym podżebrzu; usunięto też naloty włóknikowe z jelita cienkiego. Jamę ropnia zdrenowano, wyprowadzając jeden z drenów przez miejsce przebijania się ropnia pod skórę, pod XII żebrem. Przebieg pooperacyjny był niepowikłany, w 2. dobie wdrożono odżywianie doustne i kontynuowano rozpoczętą przed operacją antybiotykoterapię do czasu uzyskania wyniku posiewu. Z drenów ewakuowała się treść ropna, której objętość stopniowo się zmniejszała. Na podstawie badania bakteriologicznego ropy z jamy brzusznej wykazano brak bakterii tlenowych. Obecne były natomiast nieliczne kolonie bakterii beztlenowej Fusobacterium species, która była wrażliwa na zastosowane antybiotyki.

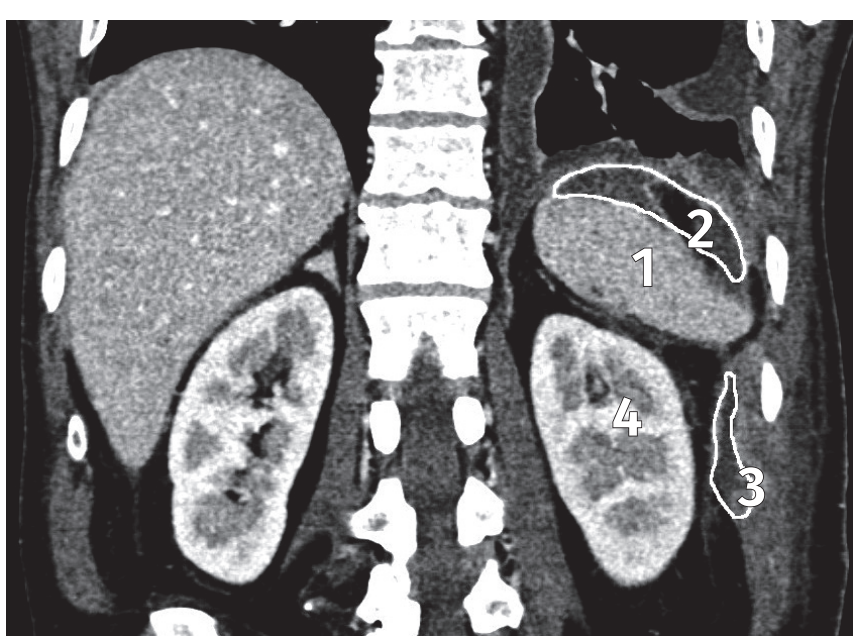

RYCINA 4. Kontrolna tomografia komputerowa jamy brzusznej w projekcji p-a, 2 tygodnie po operacji, 1 - śledziona; 2 - resztkowy zbiornik płynu nad śledzioną; 3 - resztkowy naciek zaotrzewnowy; 4 - lewa nerka

Dreny ostatecznie usunięto w 4. i 5. dobie pooperacyjnej, leczenie antybiotykiem zakończono, a pacjenta wypisano do domu 10 dni po operacji w stanie dobrym. Z miejsca po usuniętym drenie, które zabezpieczono workiem stomijnym, ewakuowało się przez tydzień ok. 20-30 mL gęstej treści ropnej na dobę, po czym wypływ treści ustał. Na podstawie kontrolnej TK jamy brzusznej wykonanej 2 tyg. po wypisaniu pacjenta wykazano obecność niewielkiego zbiornika płynu w lewej przestrzeni podprzeponowej, nad śledzioną i resztkowy naciek zapalny w lewej przestrzeni zaotrzewnowej, co nie powodowało objawów klinicznych (ryc. 4). Biochemiczne parametry stanu zapalnego utrzymywały się na podwyższonym poziomie: $\mathrm{L}=13 \mathrm{G} / \mathrm{L}$ i stężenie CRP = $124 \mathrm{mg} / \mathrm{L}$, co skłoniło lekarzy do wdrożenia ponownie antybiotykoterapii.

\section{DYSKUSJA}

Opisany przypadek samoistnego ropnia przestrzeni zaotrzewnowej, przebijającego się do jamy otrzewnowej jest interesujący z kilku powodów:
1. Nieokreślona przyczyna rozwinięcia się tak dużego zbiornika treści ropnej u dotychczas zdrowego pacjenta, nieobciążonego innymi chorobami.

2. Znaczne rozmiary ropnia.

3. Przebicie i wylanie się treści do jamy otrzewnowej, przy jednocześnie braku objawów brzusznych (otrzewnowych).

4. Stosunkowo krótki, 1-tygodniowy wywiad chorobowy wskazujący na to, że ropień przez długi czas rozwijał się bezobjawowo.

5. Nietypowa bakteria wyhodowana z ropnia (Fusobacterium species) i niewielka kolonizacja bakteryjna tak dużego zbiornika ropy.

Wszystkie te okoliczności były inspiracją do opisania tego przypadku, ponieważ w piśmiennictwie nie znaleziono podobnego. Dostępne są opisy pojedynczych przypadków dużych ropni w przestrzeni zaotrzewnowej, w których jednak udało się określić przyczynę ich powstania. Najczęściej opisywane są ropnie w prawej dolnej przestrzeni zaotrzewnowej, jako powikłanie zakątniczo położonego, perforowanego wyrostka robaczkowego [1, 2, 3, 4]. We wszystkich przypadkach autorzy podkreślają kilka wspólnych cech tych ropni:

1. Częstą pozabrzuszną manifestację kliniczną ropni zaotrzewnowych (ból w okolicy lędźwiowej, krzyżowej, na udzie).

2. Stosunkowo długi czas bezobjawowego narastania.

3. Istotną rolę badania TK jamy brzusznej w ustaleniu rozpoznania.

Cacurri i wsp. opisali przypadek 67-letniego pacjenta, który zgłosił się na oddział ratunkowy z powodu silnego bólu w lewym dole biodrowym, lewym udzie oraz gorączki. Na podstawie wyników TK jamy brzusznej wykazano rozległy ropień zaotrzewnowy w okolicy lewego podbrzusza, przechodzący na ścianę jamy brzusznej i lewe udo, na mięsień biodrowo-lędźwiowy. Pacjent został zakwalifikowany do pilnej laparotomii, która wykazała perforowany do przestrzeni zaotrzewnowej guz okrężnicy zstępującej; był on przyczyną powstania rozległego ropnia [5].

Sadatomo i wsp. opisali przypadek 71-letniej pacjentki diagnozowanej z powodu trwającego miesiąc bólu okolicy lędźwiowej oraz utraty apetytu. Wynik TK jamy brzusznej ujawnił ropień przestrzeni zaotrzewnowej położony za dwunastnicą, a duodenoskopii, że przyczyną powstania ropnia była perforacja wrzodu części poziomej dwunastnicy. Pacjentka była leczona przez laparotomię, wycięcie części dwunastnicy z owrzodzeniem, z zespoleniem dwunastniczo-czczym i drenażem ropnia zaotrzewnowego [6].

Barillaro i wsp. przedstawili podobny przypadek ropnia zaotrzewnowego u 83-letniej kobiety przyjętej do szpitala z powodu nagłego bólu całego brzucha promieniującego do okolicy lędźwiowej, którego powodem było przedziurawienie uchyłka dwunastnicy do przestrzeni zaotrzewnowej. Rozpoznanie zostało ustalone na podstawie TK jamy brzusznej, a leczenie operacyjne przez laparotomię polegało na ewakuacji ropnia przez laparotomię oraz jego zewnętrznym i wewnętrznym (dodwunastniczym) drenażu. Pomimo ciężkiego stanu i podeszłego wieku pacjentka przeżyła [7]. 
Mallia i wsp. opisali przypadek ropnia zaotrzewnowego u 88-letniego pacjenta chorującego na cukrzycę. Został on przyjęty do szpitala z powodu trwającego miesiąc bólu lewego uda, który uniemożliwiał normalne chodzenie (obciążanie lewej kończyny dolnej). Przy przyjęciu pacjent był w stanie septycznym, z objawami zakażenia układu moczowego po stronie lewej, a wynik TK jamy brzusznej i lewego uda ujawnił rozległy ropień zaotrzewnowy sięgający od lewej nerki aż do mięśni lewego uda. Pomimo szybkiego drenażu ropnia i kilkulekowej antybiotykoterapii pacjent zmarł. Nie ustalono, co było przyczyną powstania ropnia [8].

Ofrim i Legrand przedstawili przypadek 53-letniego mężczyzny, u którego ropień przestrzeni zaotrzewnowej rozwinął się w ciągu 4 dni po laparoskopowym wycięciu zgorzelinowego, perforowanego, położonego zakątniczo wyrostka robaczkowego. Stan pacjenta nagle pogorszył się w 4. dobie po operacji, z objawami posocznicy, wysokimi parametrami stanu zapalnego i prokalcytoniny. Wynik badania TK jamy brzusznej wskazał na rozległy ropień przestrzeni zaotrzewnowej po stronie prawej sięgający od dolnego bieguna prawej nerki do prawej kości krzyżowej. Inaczej niż we wcześniej opisywanych przypadkach, ewakuację i drenaż ropnia przeprowadzono od strony lędźwiowej, przez prawostronną lumbotomię. Leczenie było skuteczne, ale zdrowienie było powolne i pobyt pacjenta w szpitalu trwał miesiąc. Badanie bakteriologiczne wykazało zakażenie bakteriami beztlenowymi Acinetobacter i Flavobacterium [2]

Milewski i Szczepanek opisali przypadek 19-letniego pacjenta, który w ciągu roku był kilkakrotnie hospitalizowany i 3-krotnie operowany z powodu ropni zaotrzewnowych w obrębie prawego mięśnia biodrowo-lędźwiowego i sięgających aż do talerza biodrowego. W czasie ostatniej operacji stwierdzono, że jedna z komór ropnia zaotrzewnowego sięgała do prawego stawu biodrowego, a druga do spojenia łonowego. Właściwe rozpoznanie przyczyny powstawania ropni - chorobę Leśniowskiego-Crohna ustalono w trakcie trzeciej hospitalizacji, na podstawie wyników badań obrazowych i histologicznych wyciętego fragmentu jelita cienkiego [9]. Podobny przypadek w przebiegu choroby LeśniowskiegoCrohna opisali Veroux i wsp. [10].

Hsieh i wsp. dokonali metaanalizy piśmiennictwa prezentującego przypadki ostrego zapalenia wyrostka robaczkowego powikłanego wytworzeniem się ropni zaotrzewnowych. W piśmiennictwie z lat 1955-2005 znaleziono opisy 24 przypadków takiej patologii, z których 21 (87\%) dotyczyło osób dorosłych, a 7 (29\%) osób w wieku podeszłym. W żadnym przypadku choroba nie przebiegała typowo, a tylko 9 (37\%) pacjentów miało dolegliwości brzuszne. Odstęp między pierwszymi objawami a rozpoznaniem wynosił średnio 16 dni, a właściwa diagnoza opierała się w większości przypadków na wyniku badania TK brzucha, które ujawniło obecność ropni zaotrzewnowych, a u części chorych ropowicę zajmującą okolicę okołonerkową, mięśnie pośladkowe, tylną część uda i boczną ścianę jamy brzusznej. Leczenie polegało na appendektomii, ewakuacji i drenażu ropnia/ropowicy zaotrzewnowej, najczęściej przez okolicę lędźwiową. Z powodu posocznicy zmarły 4 osoby (17\%). Pozostali chorzy wyzdrowieli, a średni czas pobytu w szpitalu wynosił 27 dni [4].

Warto także wspomnieć o wyhodowanym u pacjenta drobnoustroju. Fusobacterium species jest beztlenową pałeczką podobną do bakterii rodzaju Bacteroides. Jest obecnie uważana za florę patogenną, choć do niedawna była traktowana jako fizjologiczna, bytująca w jamie ustnej i nosowej. Może powodować różne schorzenia ropne w obrębie jamy ustnej, powierzchowne owrzodzenia skóry, ale także zakrzepowe zapalenie żyły szyjnej wewnętrznej z posocznicą - tzw. zespół Lemierre'a, który jest schorzeniem o ciężkim, obarczonym dużą śmiertelnością przebiegu [11].

\section{PIŚMIENNICTWO}

1. Fanning DM, Barry M, O’Brien GC, Leahy AL. Perforation of a retrocaecal appendix presenting clinically as a right lumbar abscess. Surgeon 2007;5(6):368-70.

2. Ofrim OI, Legrand MJ. Retroperitoneal abscess resulting from perforated retrocecal appendicitis: a case report. Acta Chir Belg 2013;113(2):149-51.

3. Hsieh CH, Wang YC, Yang HR, Chung PK, Jeng LB, Chen RJ. Extensive retroperitoneal and right thigh abscess in a patient with ruptured retrocecal appendicitis: an extremely fulminant form of a common disease. World J Gastroenterol 2006;12(3):496-9.

4. Hsieh CH, Wang YC, Yang HR, Chung PK, Jeng LB, Chen RJ. Retroperitoneal abscess resulting from perforated acute appendicitis: analysis of its management and outcome. Surg Today 2007;37(9):762-7.

5. Cacurri A, Cannata G, Trastulli S, Desiderio J, Mangia A, Adamenko O, et al. A rare case of perforated descending colon cancer complicated with a fistula and abscess of left iliopsoas and ipsilateral obturator muscle. Case Rep Surg 2014;2014:128506. doi: 10.1155/2014/128506.

6. Sadatomo A, Koinuma K, Zuiki T, Lefor AT, Yasuda Y. Retroperitoneal abscess associated with a perforated duodenal ulcer. Clin J Gastroenterol 2013;6(5):373-7.

7. Barillaro I, Grassi V, De Sol A, Renzi C, Cochetti G, Corsi A, et al. Endoscopic rendez-vous after damage control surgery in treatment of retroperitoneal abscess from perforated duodenal diverticulum: a techinal note and literature review. World J Emerg Surg 2013;8:26. doi: 10.1186/1749-7922-8-26.

8. Mallia AJ, Ashwood N, Arealis G, Galanopoulos I. Retroperitoneal abscess: an extra-abdominal manifestation. BMJ Case Rep 2015. doi: 10.1136/ bcr-2014-207437.

9. Milewski A, Szczepanek A. Choroba Leśniowskiego-Crohna u 19-letniego mężczyzny powikłana ropniami zaotrzewnowymi i zapaleniem prawego stawu biodrowego. Wiad Lek 2013;66:244-8.

10. Veroux M, Angriman I, Ruffollo C, Fiamingo P, Caglia P, Madia C, et al. Psoas abscess: a rare complication of Crohn's disease. Acta Chir Belg 2004;104(2):187-90.

11. Su CP, Huang PY, Yang CC, Lee MH. Fusobacterium bacteremia: clinical significance and outcomes. J Microbiol Immunol Infect 2009;42(4):336-42. 